\title{
Agro-morphological Variability of Barley under Normal and Late Sown Conditions in Chitwan, Nepal
}

Chiranjibi Poudyal $^{1}$, Santosh Pathak ${ }^{1 @}$, Bishnu Raj Ojha ${ }^{2}$ and Santosh Marahatta ${ }^{2}$

${ }^{1}$ Institute of Agriculture and Animal Science, Kirtipur, Kathmandu; @: santoshpathak153@gmail.com,

ORCID: http://orcid.org/0000-0002-4689-4711 ; CP: chirupoudyal@ gmail.com

${ }^{2}$ Faculty of Agriculture, Agriculture and Forestry University, Chitwan; BRO: brojha@afu.edu.np; SM: smarahatta@afu.edu.np

Received 11 Jan 2018, Revised 17 June 2018, Accepted 7 Aug 2018, Published 28 April 2019

Scientific Editors: Jiban Shrestha, Bal K. Joshi, Neena Amatya Gorkhali

Copyright (C) 2019 NARC. Permits unrestricted use, distribution and reproduction in any medium provided the original work is properly cited.

The authors declare that there is no conflict of interest.

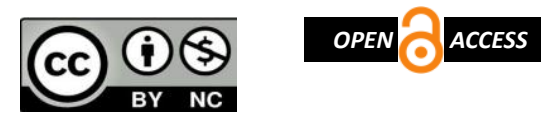

Licensed under the Creative Commons AttributionNonCommercial 4.0 International (CC BY-NC 4.0)

\begin{abstract}
Agro-morphological traits serve as an indirect selection criteria for developing new cultivars with superior performance ability. In order to study variability of agro-morphological traits of exotic barley genotypes under normal and late sown conditions, a field experiment was conducted at the research field of Institute of Agriculture and Animal Science, Chitwan, Nepal in 2015. Altogether, 13 genotypes of barley were sown under two factor factorial RCBD with three replications in two dates. Normal sowing was done on 29 Nov 2014 while late sowing was done on 1 Jan 2015. Agro-morphological traits were found to be varying significantly in late sowing condition as compared to normal one. The mean number of days to booting and heading reduced by $15.19 \%$ and $9.64 \%$, respectively in late sown condition. Similarly, plant height reduced by $19.53 \%$, peduncle length by $16.62 \%$, flag leaf width by $42.87 \%$, flag leaf area by $36.44 \%$ and FL-1 leaf area by $36.51 \%$ in late sown condition. Biomass, grain yield and harvest index were also found to be reduced by $39.66 \%, 69.77 \%$ and $46.48 \%$, respectively for late sowing condition. Nepalese landrace Soluwa performed better in normal sown condition while exotic genotype SBYT 14-1 performed better in late sown condition. SBYT 14-27 and SBYT 14-38 genotypes exhibited stable yield in both sowing conditions. Stability attribute provides an avenue for further study of such promising genotypes from agronomic and breeding perspectives under varying edaphic and agronomic conditions, and also open up the possibility of developing best performing cultivar of barley for lower plain region of the country.
\end{abstract}

Key words: Barley, agro-morphological traits, normal sowing, late sowing

सारांश

कुनै पनि बालीको उच्च उत्पादन दिने प्रजातिको छनोट र विकास कार्यमा बोटको बाह्य प्रारुपले अप्रत्यक्ष मापदण्डको भूमिका निर्वाह गर्दछ । वि.सं.२०७२ सालमा रामपुर, चितवनमा जौ बालीका विदेशी प्रजातिहरुमा बिऊ छर्ने समयले बोटको प्रारुप र उत्पादनमा पार्ने प्रभाव मुल्यांकन गर्ने उद्देश्यका साथ दुई मिति (उचित समय मड़्सर १३ गते र ढिलो समय पौष १३ गते) मा १३ प्रजातिहरु प्रयोग गरी दुई कारक आर.सी.बि.डी तरिकाले अनुसन्धान गरियो। अनुसन्धानको क्रममा जौ बालीलाई उचित समयमा भन्दा ढिलो गरी छर्दा बोटमा गुबो पसाउन र बाला पसाउन लाग्ने समय औचित्यपूर्ण रुपमा ऋमश: १५.१९\% र ९.६४\% ले घटेको पाइयो । त्यसैगरी, उचित समयको तुलनामा ढिलो गरी जौ बालीलाई छर्दा बोटको उचाइमा सामान्यत $१ ९ . \nvdash ३ \%$ ले, बाला तलको डाँठको लम्बाइमा १६.६२\% ले, भण्डे पातको चौडाईमा ४२.५७\% ले, भण्डे पातकै क्षेत्रफलमा ३६. ४\% ले र भण्डे पात मुन्तिरको पातको क्षेत्रफलमा ३६. ११\% ले कमी आएको देखियो । जौ बालीको कुल उत्पादन, दाना उत्पादन र फसल सूचकांक समेत उचित बाली छर्ने समयभन्दा एक महिना ढिलो गरी छर्दा कमश: ३९.६६\%, ६९.७७\% र ४६. ४५\% ले औचित्यपूर्ण रुपमा घटेको पाइयो। अनुसन्धानका क्रममा बालीलाई उचित समयमा छर्दा जौको नेपाली रैथाने सोलुवा प्रजातिले र ढिलो छर्दा आयातित एस.बि.वाई.टी १४-१ ले राम्रो उत्पादन दिएको पाइयो भने एस.बि.वाई.टी १४-२७ र एस.बि.वाई.टी १४-३६ प्रजातिहरुले दुवै समयमा लगभग स्थिर उत्पादन दिएको पाइयो। ढिलो छर्दा पनि धेरैका साथसाथै स्थिर उत्पादन दिने विदेशी जातहरुको विभिन्न परिवेशमा अभै विस्तृत अध्ययन गरेर तिनीहरुलाई जौको कम उत्पादन हुने ठाउँहरुमा उपयुक्त हुने किसिमको नयाँ जातको रुपमा विकास गर्ने सम्भावनालाई यस अनुसन्धानले बढावा दिनेछ।

\section{INTRODUCTION}

Barley (Hordeum vulgare L., 2n=2x=14) is a self-pollinating diploid cereal crop (Bothmer 1992). It occupies 9.4\% of the total cereal acreage with $7.8 \%$ of the total cereal production in the world (FAOSTAT 2013). Due to its wider adaptability, it is popularly grown in temperate areas as a summer crop and in tropical areas as a winter crop. It is a short season rabi cereal possessing drought tolerant ability (McGee 1986). In Nepal, barley is the most important crop from cultural perspectives but consumed much less as food. The advantages of growing barley includes erosion control, recycling of nutrients, suppression of weeds and pests, restructuring of soil, and establishing forage/legume stand (SARE 2012). Barley is the only domesticated species emerging from genus Hordeum (USDA 1979). Barley demonstrates marked variation in vegetative, phenological and grain traits when sown beyond normal season (Savin 
et al 1997; Mohammadi 2002; Pathak et al 2017). The optimum performance of crop is also hampered when sown beyond the normal time. According to Mollasadeghi et al (2011), study of agro-morphological traits is pivotal in determining the importance of each trait in relation to increasing crop yield along with the use of those traits in breeding programs for introducing commercial varieties. Agro-morphological traits can also be used as criteria for indirect selection leading to new cultivars with high yield stability and superior performance in dry environments (Ahmadizadeh 2013). Moreover, morphological traits also serve as a criterion for the estimation of genetic diversity and management of crop germplasm collection (Chandran and Pandya 2000; Ariyo 1993). Researches by Chand et al (2008) and Papa et al (1998) have shown that grain yield is the resultant product of action and interaction of numerous components such as plant height, harvest index, number of tillers, number of grain per spike and the like. Furthermore, controlling the inheritance of agro-morphological characters correlated with crop productivity becomes helpful in framing an efficient and effective breeding program (Eshghi and Akhundova 2010). Most of the studies relating to agro-morphological traits of barley in Nepal are concerned with landraces and conducted in the Hilly region (Amgai et al 2011; Gupta et al 2009; Riley and Singh 1989). However, studies concerning characterization of exotic genotypes in low lying regions- plains of the Terai or inner Terai region- of the country have been rarely evidenced. Hence, this research was conducted with the primary objective of characterizing agromorphological traits of different exotic barley genotypes under varying dates of sowing; evaluating genotypic variability and relative performance of barley in the inner Terai region at varying sowing conditions; and identifying best performing exotic barley genotype under given set of agro-environmental conditions.

\section{MATERIALS AND METHODS}

This field experiment was conducted at Institute of Agriculture and Animal Science (IAAS), Rampur, Chitwan (27 $37^{\prime} \mathrm{N}$ latitude, $84^{\circ} 25^{\prime} \mathrm{E}$ longitude and $198 \mathrm{~m}$ above sea level) in barley growing season from November 2014 to April 2015. Barley (Hordeum vulgare L., $2 \mathrm{n}=2 \mathrm{x}=14$ ) was sown on normal (29 Nov 2014) and late (1 Jan 2015) dates. Normal sown condition is also the representation of optimum sowing time. The experimental genotypes (Table 1) included a landrace from Hill Crop Research Program (HCRP)-Nepal and twelve exotic lines from International Center for Agricultural Research in Dry Areas (ICARDA)-Morocco.

Table 1. List of different genotypes of barley used in the field experiment and their pedigree

\begin{tabular}{lll}
\hline Genotype & \multicolumn{1}{c}{ Cross/Pedigree } & Origin \\
\hline SBYT 14-1 & Alanda/5/Aths/4/Pro/TolI//Cer*2/TolI/3/5106/6/Baca'S'/3/AC253//CI08887/CI05761 & ICARDA, Morocco \\
\hline SBYT 14-2 & Zarjau/80-5151//OK84817 & ICARDA, Morocco \\
\hline SBYT 14-5 & Avt/Attiki//M-Att-73-337-1/3/Aths/Lignee686/4/Lignee527/NK1272//JLB70-63 & ICARDA, Morocco \\
\hline SBYT 14-7 & Rhn-03/Alanda & ICARDA, Morocco \\
\hline SBYT 14-8 & Clipper//WI2291*2/WI2269/7/Hml-02/5/Cq/Cm//Apm/3/12410/4/Giza134- & ICARDA, Morocco \\
& 2L/6/Clipper/Volla/3/Arr/Esp//Alger/Ceres362-1-1/4/Hml & ICARDA, Morocco \\
\hline SBYT 14-9 & Nadawa/Rhn-03//Saida & ICARDA, Morocco \\
\hline SBYT 14-11 & Aths/Lignee686/4/Avt/Attiki//Aths/3/Giza121/Pue & ICARDA, Morocco \\
\hline SBYT 14-18 & QB813-2/5/Aths/Lignee686/4/Rhn-03/3/Bc/Rhn//Ky63-1294 & ICARDA, Morocco \\
\hline SBYT 14-27 & Alanda//Ssn/Lignee640/3/QB813-2 & ICARDA, Morocco \\
\hline SBYT 14-37 & Alanda/5/Aths/4/Pro/TolI//Cer*2/TolI/3/5106/6/Aths/CI16155 & ICARDA, Morocco \\
\hline SBYT 14-38 & Rhn-03/AC_Bacon & ICARDA, Morocco \\
\hline SBYT 14-39 & Rihane-03 & HCRP, Nepal \\
\hline Soluwa & NB 1054/Solukhumbu (Landrace) & \\
\hline Note: SBYT $=$ Spring Barley Yield Trial, ICARDA= International Center for Agricultural Research in the Dry Areas. &
\end{tabular}

Treatments of each individual sowing date were arranged in Randomized Complete Block Design (RCBD) with three replications. The size of each plot was $1.2 \mathrm{~m}$ by $2.5 \mathrm{~m}$ with 6 rows in a plot and thirteen plots per replication. Each replicates were separated by $0.5 \mathrm{~m}$ distance. Normal and late sown crops were separated at $1 \mathrm{~m}$ distance. Standard cultivation practices of barley were used. Land preparation was done by plowing with rotavator two times followed by leveling. Sowing was done by placing seeds in small furrows. Due to exotic nature of genotypes, fertilizers were applied basally at the rate of 120:60:40 kg NPK per hectare. Weed management was done manually 
on 25 days after sowing for each dates. No irrigation was provided to the crop due to adequate moisture availability from precipitation. Harvesting was done when crop matured. Soil was sandy loam in texture with $\mathrm{pH}$ 5.5, organic carbon $1.2 \%$, phosphorus $31.5 \mathrm{~kg} / \mathrm{ha}$ and potassium $93.9 \mathrm{~kg} / \mathrm{ha}$. Total rainfall during cropping period was 119.70 $\mathrm{mm}$ and relative humidity ranged from $17.15 \%$ to $69.24 \%$. Mean temperatures during crop growth period were $19.39^{\circ} \mathrm{C}$ and $20.90^{\circ} \mathrm{C}$ in normal and late sowing condition respectively. (Figure 1).

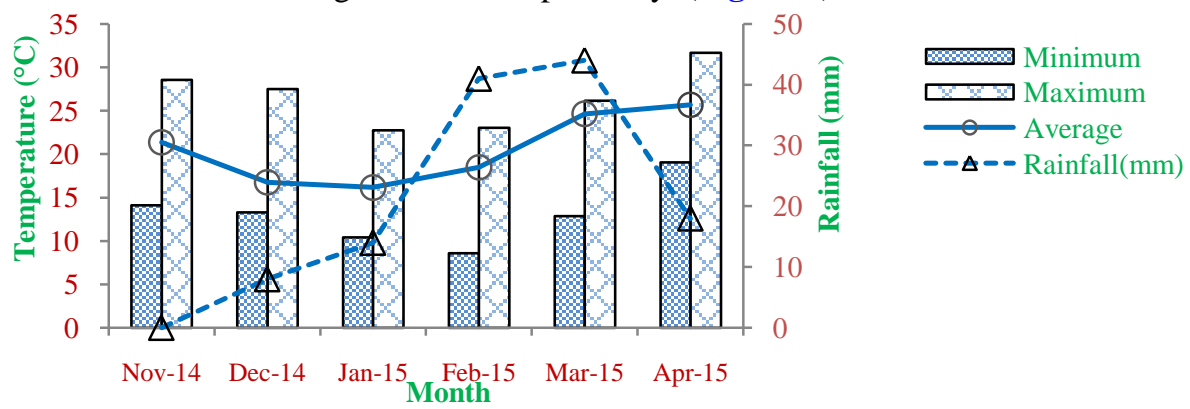

Figure 1. Monthly weather distribution at research site in Chitwan, Nepal from Nov 2014 to Apr 2015.

For the purpose of recording quantitative data on agro-morphological traits, ten plants were tagged randomly from each plot; however, whole plot was taken into consideration for recording data on days to booting, days to heading, biological yield and grain yield. Grain yield was calculated according to the formula suggested by Leonard (1984) as:

$$
\text { Grain yield }(\mathrm{kg} / \mathrm{ha})=\frac{10000 \times \text { Plot yield }(\text { in } \mathrm{kg})}{\text { Plot area }\left(\text { in }^{2}\right)}
$$

Harvest index (HI) was calculated by using the formula given by Chandrasekaran et al (2010) as:

$$
\mathrm{HI}=\frac{\text { Grain Yield }}{\text { Biomass Yield }}
$$

Microsoft Office Excel 2007 was used for recording the observed data; performing simple statistical analysis; and generating tables and graphs. The recorded data were further subjected to analysis of variance and Duncan's Multiple Range Test (DMRT) by using GenStat $15^{\text {th }}$ Edition and setting 5\% level of significance.

\section{RESULTS}

Different barley genotypes exhibited striking variability in their agro-morphological traits during field experiment under normal and late sown conditions. Variability in phenological and vegetative traits of barley was due to influence of temperature change between two sowing dates and varying degree of response of different genotypes to that change. Both genotypes and environment contributed to variability of different agro-morphological traits.

\begin{tabular}{|c|c|c|c|c|c|c|c|c|c|c|c|c|}
\hline $\begin{array}{l}\text { Sources of } \\
\text { variation }\end{array}$ & df & $\begin{array}{l}\text { Days to } \\
\text { booting }\end{array}$ & $\begin{array}{l}\text { Days to } \\
\text { heading }\end{array}$ & $\begin{array}{l}\text { Flag } \\
\text { leaf } \\
\text { length }\end{array}$ & $\begin{array}{l}\text { Flag } \\
\text { leaf } \\
\text { width }\end{array}$ & $\begin{array}{l}\text { Flag } \\
\text { leaf } \\
\text { area }\end{array}$ & $\begin{array}{l}\text { FL-1 } \\
\text { leaf } \\
\text { area }\end{array}$ & $\begin{array}{l}\text { Plant } \\
\text { height }\end{array}$ & $\begin{array}{l}\text { Peduncle } \\
\text { length }\end{array}$ & Biomass & $\begin{array}{l}\text { Grain } \\
\text { yield }\end{array}$ & $\begin{array}{l}\text { Harvest } \\
\text { index }\end{array}$ \\
\hline Replication & 2 & 0.2 & 24.6 & 3.4 & 0.004 & 1.8 & 5.6 & 32 & 2.7 & $1.0 \mathrm{e}^{6}$ & $6.5 \mathrm{e} 5$ & $3.98 \mathrm{e}-3$ \\
\hline Genotype & 12 & $153.8 * *$ & $100.8 * *$ & $21.5^{* *}$ & $0.178 * *$ & $24.1 * *$ & $36.2 * *$ & $110.3 * *$ & $116.2 * *$ & $1.5 \mathrm{e} 7 *$ & $3.5 \mathrm{e} 6 * *$ & $2.53 \mathrm{e}-2 * *$ \\
\hline Sowing time & 1 & $2954.6^{* *}$ & $1411.1 * *$ & 0.5 & $4.279 * *$ & $261.9 * *$ & $958.3^{* *}$ & $4327 * *$ & $296.2 * *$ & $3.4 \mathrm{e} 8 * *$ & $1.2 \mathrm{e} 7 * *$ & $3.38 \mathrm{e}-2 * *$ \\
\hline $\begin{array}{l}\text { Genotype } \times \\
\text { sowing time }\end{array}$ & 12 & $32.0 * *$ & $17.6^{* *}$ & 6.8 & 0.038 & 7.1 & 14.9 & $67.5^{* *}$ & $27.0 * *$ & $1.6 \mathrm{e} 7 *$ & $1.8 \mathrm{e} 6^{* *}$ & $5.54 \mathrm{e}-3^{*}$ \\
\hline Residual & 50 & 4.5 & 4.5 & 3.8 & 0.030 & 5.0 & 9.4 & 20.5 & 4.4 & $5.6 \mathrm{e} 6$ & $3.9 \mathrm{e} 5$ & $2.17 \mathrm{e}-3$ \\
\hline
\end{tabular}

Table 2. Mean sum of squares from ANOVA of different agro-morphological traits of barley

The combined analysis of variation (Table 2) revealed that the effects of genotypes and sowing time were significant for all traits including days to booting, days to heading, flag leaf width, flag leaf area, FL-1 leaf (first leaf below the flag leaf) area, plant height, peduncle length, biomass, grain yield and harvest index, except flag leaf length where effect of sowing time was insignificant. In addition to that, interaction effect was also highly significant for phenological traits like days to booting and days to heading including plant height, peduncle length, biomass, grain yield and harvest index. 


\section{Days to Booting}

During the field experiment, the average days to booting for barley was about 73 days (Table 3). The days to booting for genotypes sown in normal (November) planting condition was about 79 days and it was significantly greater than days to booting for late (January) planting condition (67 days). The earliest days to booting (64 days) was recorded in Soluwa while booting was most delayed (81 days) in SBYT 14-7. The mean days to booting was reduced by $15.19 \%$ (12 days) in late sown condition compared to the normal one. And, this reduction was statistically significant at $5 \%$ significance level. Interaction between days to booting and sowing time is shown in Figure 2.

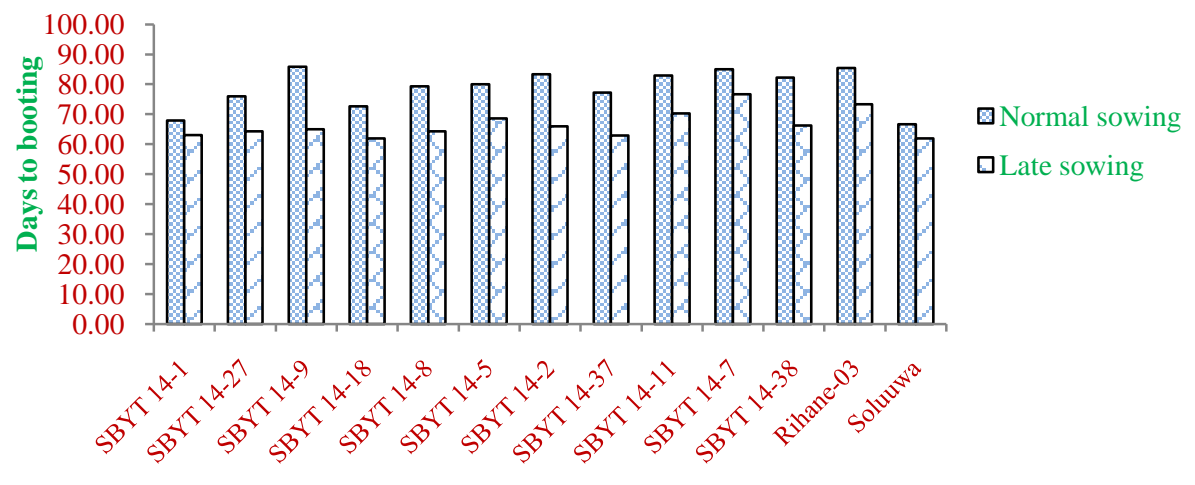

Genotypes

Figure 2. Genotypexsowing time interaction for days to booting of barley under different sowing conditions.

\section{Days to Heading}

The mean days to heading of barley was observed to be 79 days (Table 3 ). The days to heading for normal sown condition was about 83 days and it was significantly higher than days to heading for late sown condition (75 days). The earliest days to heading was recorded in Soluwa (72 days) while last heading was recorded in SBYT 14-7 (84 days). On an average, the days to heading was reduced by $9.64 \%$ (8 days) in delayed sowing when compared with the normal sowing condition.

\section{Flag Leaf Length}

The average flag leaf length of barley during the field experiment was recorded to be $14.04 \mathrm{~cm}$ (Table 3). The flag leaf length during normal sown condition $(13.96 \mathrm{~cm})$ and late sown condition $(14.12 \mathrm{~cm})$ were statistically indifferent at 5\% significance level. The longest flag leaf length $(17.59 \mathrm{~cm})$ was recorded in SBYT 14-1 and the shortest $(10.98 \mathrm{~cm})$ was recorded in SBYT 14-18. The flag leaf length remained statistically unchanged with sowing time at $5 \%$ significance level. The interaction effect of flag leaf length with respect to genotypes and sowing time is given in Figure 3.

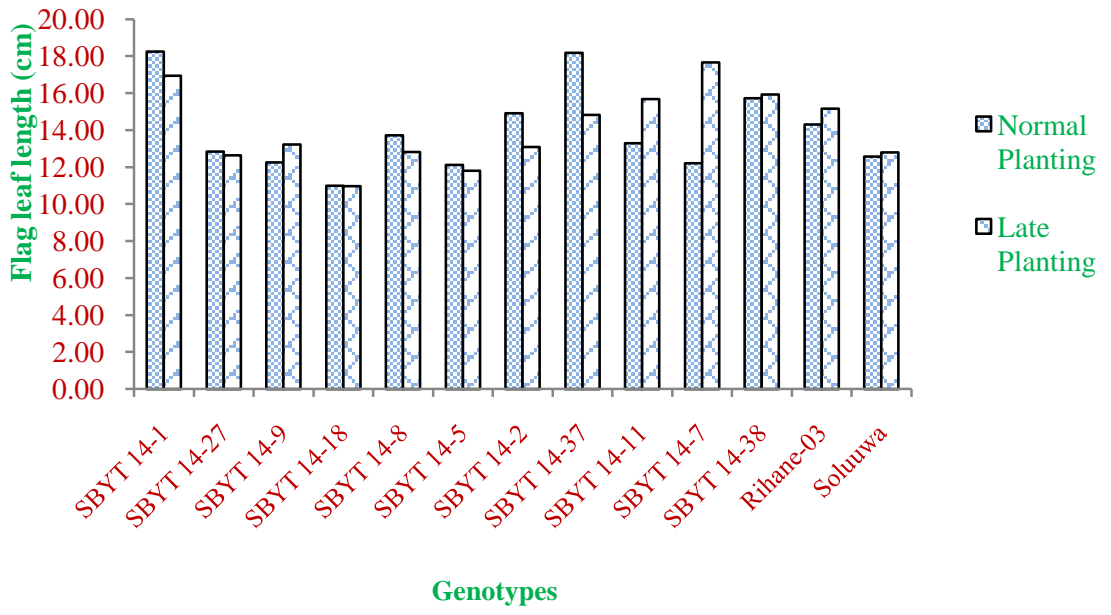

Figure 3. Genotypexsowing time interaction for flag leaf length of barley under different sowing conditions. 
Flag Leaf Width

The mean width of flag leaf of barley was recorded to be $0.700 \mathrm{~cm}$ and ranged from $0.509 \mathrm{~cm}$ to $0.891 \mathrm{~cm}$ on the basis of sowing time (Table 3). The widest flag leaf was recorded in SBYT 14-37 (0.819 cm) and the narrowest was recorded in SBYT 14-5 $(0.437 \mathrm{~cm})$. While comparing with normal sown condition, barley flag leaf width, on an average, was found to be significantly reduced by $42.87 \%(0.38 \mathrm{~cm})$ during late sown condition

Flag Leaf Area

Flag leaf has crucial role to synthesize and translocate photo-assimilates to seeds of cereals (Biswal and Kohli 2013). The average area of flag leaf during the field experiment was recorded to be $8.24 \mathrm{~cm}^{2}$. Flag leaf area of normal sown barley genotypes $\left(10.07 \mathrm{~cm}^{2}\right)$ was statistically higher than that of late sown genotypes $\left(6.40 \mathrm{~cm}^{2}\right)$ at $5 \%$ significance level. The largest flag leaf area was recorded in SBYT 14-37 $\left(10.954 \mathrm{~cm}^{2}\right)$ and the smallest was recorded in SBYT $14-5\left(4.104 \mathrm{~cm}^{2}\right)$. The mean flag leaf area reduced significantly by $36.44 \%\left(3.67 \mathrm{~cm}^{2}\right)$ in late sown condition.

\section{FL-1 Leaf Area}

On an average, area of first leaf under the flag leaf was $15.7 \mathrm{~cm}^{2}$ and ranged from $10.52 \mathrm{~cm}^{2}$ to $19.39 \mathrm{~cm}^{2}$ among barley genotypes. FL-1 leaf area during normal sown condition $\left(19.20 \mathrm{~cm}^{2}\right)$ was significantly higher than late sown condition $\left(12.19 \mathrm{~cm}^{2}\right)$. The largest area of FL-1 leaf was recorded in SBYT 14-37 $\left(19.39 \mathrm{~cm}^{2}\right)$ while the smallest was recorded in SBYT 14-5 $\left(10.52 \mathrm{~cm}^{2}\right)$. The mean FL-1 leaf area was reduced significantly by $36.51 \%\left(7.01 \mathrm{~cm}^{2}\right)$ in late sown condition in comparison to normal sown condition.

Table 3. Means for different agro-morphological traits of barley as influenced by sowing time and genotypes

\begin{tabular}{|c|c|c|c|c|c|c|c|c|}
\hline Treatment & $\begin{array}{l}\text { Days to } \\
\text { booting }\end{array}$ & $\begin{array}{l}\text { Flag leaf } \\
\text { length } \\
(\mathrm{cm})\end{array}$ & $\begin{array}{c}\text { Flag leaf } \\
\text { width }(\mathrm{cm})\end{array}$ & $\begin{array}{c}\text { Plant } \\
\text { height } \\
(\mathrm{cm})\end{array}$ & $\begin{array}{c}\text { Peduncle } \\
\text { length }(\mathrm{cm})\end{array}$ & $\begin{array}{c}\text { Biomass } \\
\text { (kg/ha) }\end{array}$ & $\begin{array}{c}\text { Grain yield } \\
(\mathrm{kg} / \mathrm{ha})\end{array}$ & $\begin{array}{c}\text { Harvest } \\
\text { index }\end{array}$ \\
\hline \multicolumn{9}{|l|}{ Sowing Time } \\
\hline Normal & $78.20 \pm 1.00$ & $14.00 \pm 0.44$ & $0.89 \pm 0.03$ & $92.21 \pm 1.20$ & $23.46 \pm 1.04$ & $10597 \pm 228$ & $1108 \pm 229$ & $0.09 \pm 0.02$ \\
\hline Late & $66.50 \pm 0.80$ & $14.12 \pm 0.41$ & $0.51 \pm 0.02$ & $74.40 \pm 0.20$ & $19.56 \pm 0.48$ & $6394 \pm 623$ & $335.00 \pm 66.46$ & $0.05 \pm 0.01$ \\
\hline S.E.M $( \pm)$ & 0.30 & 0.31 & 0.02 & 0.73 & 0.34 & 378.60 & 100.40 & 0.03 \\
\hline LSD (0.05) & 0.10 & 0.89 & 0.05 & 2.06 & 0.95 & 1075.30 & 285.10 & 0.02 \\
\hline$F$-value & $656.86 * *$ & 0.14 & $265.98 * *$ & $308.94 * *$ & $67.47 * *$ & $61.62 * *$ & $29.72 * *$ & $15.55 * *$ \\
\hline p-level & $<0.001$ & 0.708 & $<0.001$ & $<0.001$ & $<0.001$ & $<0.001$ & $<0.001$ & $<0.001$ \\
\hline \multicolumn{9}{|l|}{ Genotypes } \\
\hline SBYT 14-1 & $65.5 a b \pm 1.1$ & $17.6 e \pm 0.9$ & $0.7 b c d e \pm 0.1$ & $81.0 a b c \pm 3.1$ & $23.6 e \pm 1.7$ & $8600 a b \pm 955$ & $1801 d e \pm 588$ & $0.19 d \pm 0.04$ \\
\hline SBYT 14-27 & $70.2 c \pm 2.7$ & $12.8 a b c \pm 0.8$ & $0.7 c d e f \pm 0.1$ & $91.6 e \pm 5.8$ & $21.4 d e \pm 1.4$ & $8343 a b \pm 662$ & $527 a b \pm 141$ & $0.06 a b c \pm 0.02$ \\
\hline SBYT 14-9 & $75.5 e \pm 4.7$ & $12.7 a b c \pm 0.5$ & $0.8 e f \pm 0.1$ & $84.3 b c d \pm 5.9$ & $17.3 a b \pm 0.6$ & $9220 a b \pm 1694$ & $96 a \pm 38$ & $0.01 a \pm 0.00$ \\
\hline SBYT 14-18 & $67.3 b \pm 2.4$ & $11.0 a \pm 0.9$ & $0.6 b c \pm 0.1$ & $88.1 d e \pm 4.1$ & $23.3 e \pm 1.7$ & $9787 a b \pm 1945$ & $1417 c d \pm 761$ & $0.10 c \pm 0.04$ \\
\hline SBYT 14-8 & $71.8 c d \pm 3.5$ & $13.3 a b c \pm 1.1$ & $0.6 b \pm 0.1$ & $77.2 a \pm 4.0$ & $21.4 d e \pm 1.4$ & $9753 a b \pm 1961$ & $1217 b c d \pm 519$ & $0.10 c \pm 0.03$ \\
\hline SBYT 14-5 & $74.3 e \pm 2.8$ & $12.0 a b \pm 0.7$ & $0.4 a \pm 0.1$ & $83.4 b c d \pm 4.4$ & $19.6 b c d \pm 1.1$ & $6713 b c \pm 521$ & $120 a \pm 50$ & $0.02 a b \pm 0.01$ \\
\hline SBYT 14-2 & $74.7 e \pm 4.0$ & $14.0 b c d \pm 1.1$ & $0.7 c d e f \pm 0.1$ & $80.0 a b c \pm 2.1$ & $16.8 a \pm 0.6$ & $4637 c \pm 942$ & $61 a \pm 16$ & $0.02 a b \pm 0.01$ \\
\hline SBYT 14-37 & $70.2 c \pm 3.2$ & $16.5 d e \pm 0.9$ & $0.8 f \pm 0.2$ & $88.6 \mathrm{de} \pm 5.7$ & $26.1 f \pm 2.6$ & $8413 a b \pm 971$ & $843 a b c \pm 192$ & $0.10 c \pm 0.02$ \\
\hline SBYT 14-11 & $76.7 e \pm 3.0$ & $14.5 b c d \pm 0.6$ & $0.8 d e f \pm 0.1$ & $81.0 a b c \pm 4.2$ & $18.3 a b c \pm 1.2$ & $9893 a b \pm 1120$ & $190 a \pm 101$ & $0.02 a b \pm 0.01$ \\
\hline SBYT 14-7 & $80.8 f \pm 2.0$ & $15.0 c d \pm 1.3$ & $0.8 e f \pm 0.1$ & $79.6 a b c \pm 4.9$ & $20.2 c d \pm 0.6$ & $8437 a b \pm 1602$ & $19 a \pm 4$ & $0.002 a \pm 0.00$ \\
\hline SBYT 14-38 & $74.3 d e \pm 3.7$ & $15.8 d e \pm 0.6$ & $0.7 c d e f \pm 0.1$ & $85.1 c d \pm 3.9$ & $20.7 c d \pm 0.4$ & $8293 a b \pm 620$ & $656 a b c \pm 204$ & $0.07 b c \pm 0.02$ \\
\hline Rihane-03 & $79.4 f \pm 2.8$ & $14.7 c d \pm 0.7$ & $0.7 c d e f \pm 0.1$ & $78.4 a b \pm 4.1$ & $18.0 a b c \pm 0.7$ & $7737 a b \pm 1598$ & $89 a \pm 15$ & $0.01 a \pm 0.00$ \\
\hline Soluwa & $64.3 a \pm 1.2$ & $13.0 a b c \pm 0.3$ & $0.7 b c d \pm 0.1$ & $83.4 b c d \pm 5.8$ & $33.1 g \pm 2.7$ & $10617 a \pm 2583$ & $2345 e \pm 701$ & $0.20 d \pm 0.03$ \\
\hline S.E.M (士) & 0.90 & 0.80 & 0.04 & 1.85 & 0.86 & 965.20 & 255.90 & 0.01 \\
\hline F-value & $34.20 * *$ & $5.67 * *$ & $6.68 * *$ & $5.38 * *$ & $26.47 * *$ & $2.59 * *$ & $2.18 *$ & $11.66 * *$ \\
\hline
\end{tabular}

Note: Means followed by same letters are not significantly different at $5 \%$ level by Duncan's Multiple Range Test (DMRT), GM= Grand Mean, \pm denotes Standard Error, SEM = Standard Error of Mean, LSD= Least Significant Difference, CV=Coefficient of Variation.

\section{Plant Height}

Plant height is morphologically important character, and it is closely linked with productive potential of plant. The mean height of barley plant during the field experiment was $83.20 \mathrm{~cm}$ and it ranged from 74.20 to $92.21 \mathrm{~cm}$ on the basis of sowing time. The tallest plant height $(91.60 \mathrm{~cm})$ was recorded in SBYT 14-27 while the shortest height $(77.15 \mathrm{~cm})$ was recorded in SBYT 14-8. In late sown condition, mean plant height reduced by $19.53 \%(18.01 \mathrm{~cm})$ and this reduction was found to be statistically significant at $5 \%$ level. Interaction between genotypes and sowing time for plant height is presented in Figure 4. 


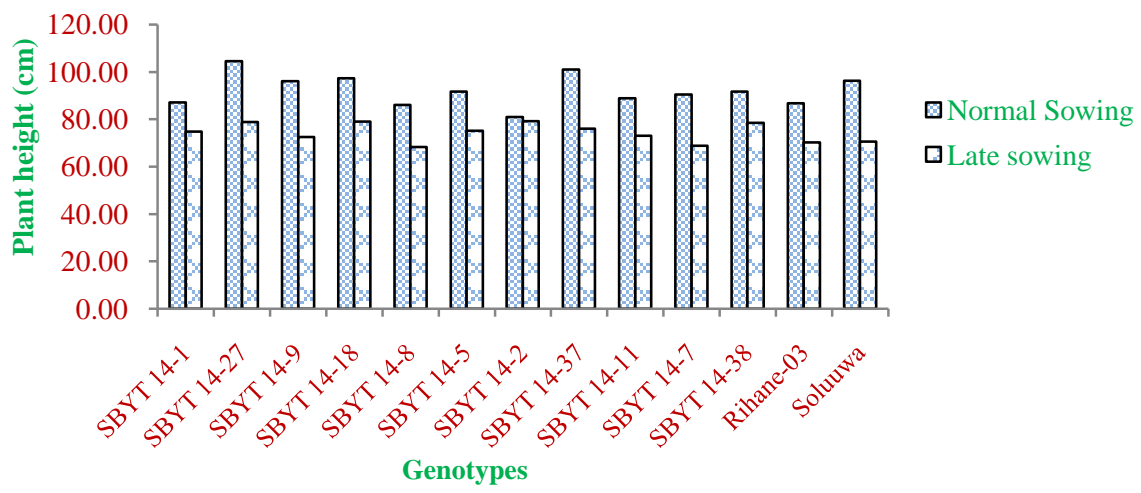

Figure 4. Genotypexsowing time interaction for plant height of barley under different sowing conditions.

\section{Peduncle Length}

Peduncle length serves as indirect selection criterion for improving yield of crop (Borner et al 2002). The average length of peduncle during the field experiment was recorded as $21.51 \mathrm{~cm}$ (Table 3). The peduncle length for genotypes during normal sown condition was $23.46 \mathrm{~cm}$ and it was significantly higher than that for late sown genotypes $(19.56 \mathrm{~cm})$. The longest peduncle length $(33.08 \mathrm{~cm})$ was recorded in Soluwa and the shortest $(16.82 \mathrm{~cm})$ was recorded in SBYT 14-2. Peduncle length reduced by $16.62 \%(3.9 \mathrm{~cm})$ in late sown condition than the normal one and this reduction was statistically significant at 5\% level. Interaction between peduncle length and sowing time is given in Figure 5.

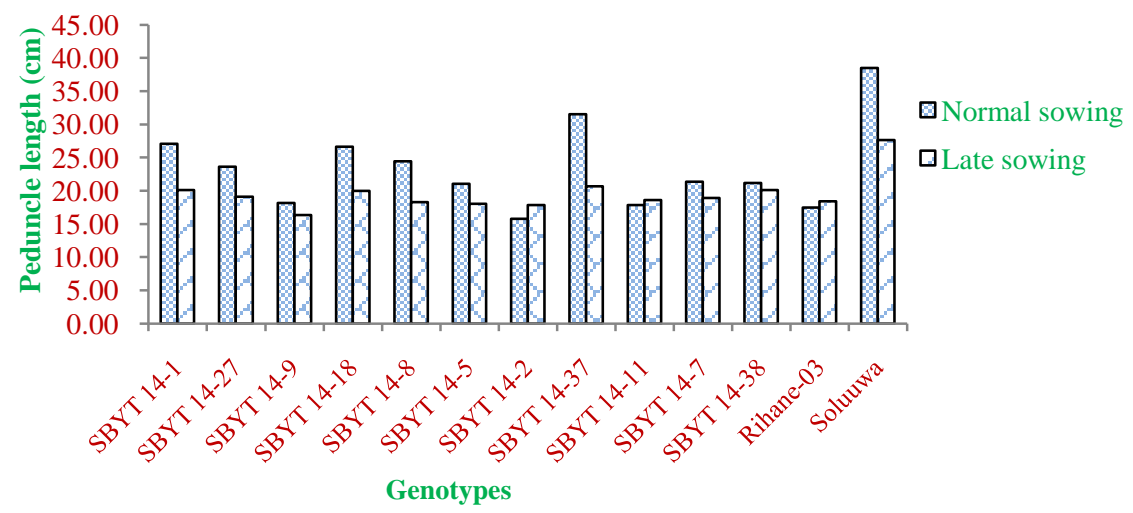

Figure 5. Genotypexsowing time interaction for peduncle length of barley under different sowing conditions.

\section{Biomass}

The mean biomass production during the field experiment of different genotypes of barley was recorded to be 8496 $\mathrm{kg} / \mathrm{ha}$ (Table 3). The biomass production under normal sown condition $(10597 \mathrm{~kg} / \mathrm{ha})$ was significantly higher than late sown condition $(6394 \mathrm{~kg} / \mathrm{ha})$. The highest biomass was recorded in Soluwa $(10617 \mathrm{~kg} / \mathrm{ha})$ and lowest biomass was recorded in SBYT 14-2 (4637 kg/ha). For all genotypes, biomass was statistically higher in normal sown condition than late one except for SBYT 14-2. This exception in SBYT 14-2 was due to heavy disease infestation in November planting date. Biomass of barley reduced by $39.66 \%(4203 \mathrm{~kg} / \mathrm{ha})$ in late sown condition. The mean straw yield was recorded to be $6895 \mathrm{~kg} / \mathrm{ha}$. The straw weight was significantly higher for normal sown condition $(8407 \mathrm{~kg} / \mathrm{ha})$ than late sown condition $(5382 \mathrm{~kg} / \mathrm{ha})$. The highest $(8611 \mathrm{~kg} / \mathrm{ha})$ and lowest $(4060 \mathrm{~kg} / \mathrm{ha})$ straw yield were recorded in SBYT 14-11 and SBYT 14-2 respectively. Straw yield was comparatively higher in normal sowing condition than late sowing condition for all genotypes except SBYT 14-2. The interaction of biomass with sowing time and genotypes is shown in Figure 6. 


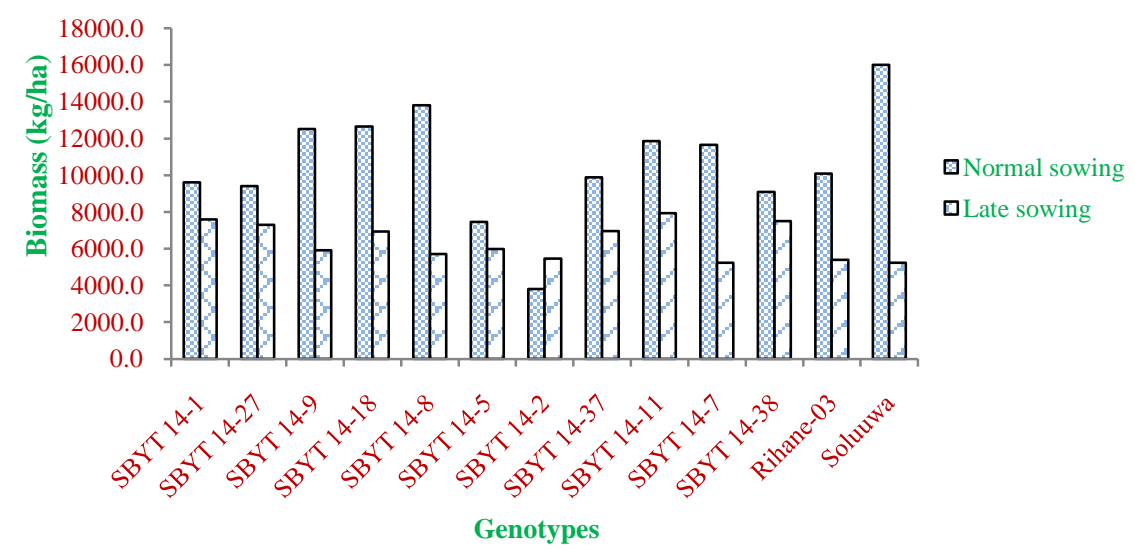

Figure 6. Genotypexsowing time interaction for biomass of barley in two different sowing conditions.

\section{Grain Yield}

Yield is a complex character; it depends on different environmental, physiological, and morphological characters. The mean grain yield of barley was recorded as $722 \mathrm{~kg} / \mathrm{ha}$ (Table 3). The average grain yield in normal sown condition $(1108 \mathrm{~kg} / \mathrm{ha})$ was significantly higher than that in late sown condition $(335 \mathrm{~kg} / \mathrm{ha})$. The highest grain yield was recorded in Soluwa $(2345 \mathrm{~kg} / \mathrm{ha})$ and lowest was recorded in SBYT 14-7 (19 kg/ha). For all the genotypes, grain yield was statistically higher in normal sown condition than late sown condition except for SBYT 14-27 and SBYT 14-2. Increase in yield was observed in later sown date for SBYT 14-2 due to heavy disease infestation in normal sown condition. Grain yield reduced drastically by $69.77 \%$, ie $773 \mathrm{~kg} / \mathrm{ha}$, in late sown condition when compared with the normal one. The variability of grain yield of barley with sowing time and genotypes is shown in Figure 7.

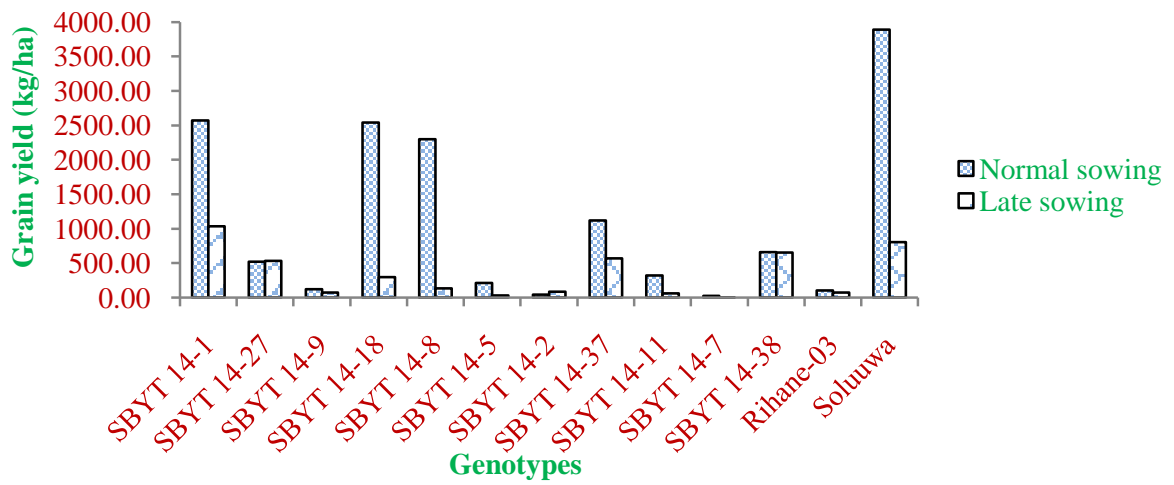

Figure 7. Genotypexsowing time interaction for grain yield of barley in two different sowing condition

\section{Harvest Index (HI)}

Harvest index signifies the relationship between economic yield and biological yield. The average harvest index of barley during the experiment was 0.0687 and ranged from 0.0479 to 0.0895 on the basis of sowing time as shown in Table 3. Soluwa had highest harvest index (0.1945). The lowest HI was of SBYT 14-7 (0.0023). There was marked decline in HI of barley by $46.48 \%$ in January planting as compared to November planting condition. The interaction between sowing time and genotypes with $\mathrm{HI}$ is reflected in Figure 8. 


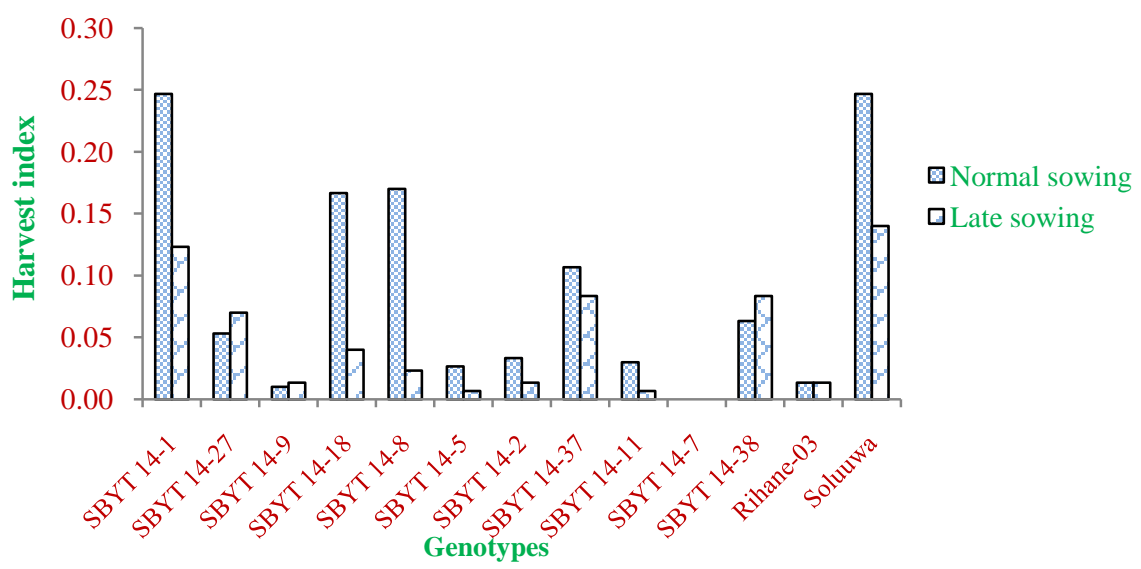

Figure 8. Genotypexsowing time interaction for harvest index of barley in different growing seasons.

\section{DISCUSSION}

Various studies have attempted to quantify the effect of sowing date on different traits of barley (Photiades and Hadjichristodoulou 1984; Alam et al 2007; Rashid et al 2010; Kirby et al 1985). These studies have reported that sowing time has considerable impact of varying degree on agro-morphology of crop. In the present study, the accelerated growth and development fostered by exposure to high temperature was the influencing reason behind the difference in days to booting within same genotype with altered planting date (Singh and Paul 2003). The decrease in number of days to heading in later sown genotypes probably resulted from slower emergence and rapid accumulation of heat units from increased temperature after February (Slafer and Whitechurch 2001). During the late sown condition, barley crop faces severe heat stress. Sensitivity of photosynthesis to heat stress and shorter vegetative growth were the casual factors for reduced leaf area in late sown dates than the normal one. This finding is in line with the works of Alam et al (2013) and Suleiman et al (2014).

Barley possesses determinate nature wherein growth of vegetative parameters is halted before initiation of reproductive phase. Plant height decreased with delay of planting date because the changes in photoperiod accelerated the development towards reproductive stages and hence less time was available for vegetative growth resulting in lesser height of genotypes sown in late condition. Okosun et al (2006) also reported similar findings for plant height in non-optimum planting date. The differences in length of the peduncle in different sowing dates were due to altered stem reserve mobilization in the plant (Asseng and Herwaarden 2003).

The process of assimilation of photosynthates is enhanced in normal temperature. The upsurge in temperature leads to rise in respiration and transpiration, ultimately reducing the stored assimilates and hence the biomass. Significant difference among the genotypes on straw yield could be due to genotypical inherited difference for redistribution capacity of soluble reserves (Ahamed et al 2010). Overall grain yield reduced in delayed sowing due to the association with high temperature. Each day delay in sowing results cereal grain yield to reduce by $21 \mathrm{~kg} / \mathrm{ha}$ (Ekeberg 1994). Higher HI among the genotypes may be due to genetic variability. But, higher HI in normal sown genotypes was due to better photosynthate redistribution efficiency from stem and leaves to straw favored by optimum temperature during normal sown condition.

Nepalese barley landrace, Soluwa, exhibited very high yield in our field experiment. But lodging was found to be a serious problem. Without addressing lodging problem, it seems challenging to realize the true benefit of cultivating Soluwa in inner Terai region. Among 12 exotic barley genotypes, SBYT 14-1 outperformed in given field condition of Chitwan. The exotic genotype SBYT 14-1 can be promising for lower regions of Nepal for the reason that it has very high yield than national average barley yield in normal season. In addition to that, the mean yield of SBYT 141 in delayed sowing condition is also around the national average yield figure $(1.33 \mathrm{Mt} / \mathrm{ha})$. By subjecting this genotype to multi-locational trial, Hilly region oriented barley cultivation can be possibly spread even in plain areas of Nepal. Yield stability is a very important property for breeding program. Exotic genotypes such as SBYT 14-27 and SBYT 14-38 exhibited lower but very stable grain yield under both normal and late sown conditions during the field experiment. This stability feature can be very important to design breeding programs in context of high yield variation due to delay in the sowing time of barley. Furthermore, the stability property of two exotic genotypes can 
be invaluable boon to breeders for augmenting barley production in those areas of Nepal where the hot temperature severely limits barley production.

\section{ACKNOWLEDGMENTS}

This research was conducted with funding and genetic materials from International Center for Agricultural Research in the Dry Areas (ICARDA), Morocco. The authors gratefully acknowledge Dr Sanjaya Gyawali, Mr Mahendra Tripathi and Asst Prof Suryamani Dhungana for technical support throughout the research process; Mr Anupam Uprety and Mr Arun Chapain for generously assisting data collection; and two referees for critical comments that helped shape the paper in this form.

\section{REFERENCES}

Ahamed KU, K Nahar and M Fujita. 2010. Sowing date mediated heat stress affects the leaf growth and dry matter partitioning in some spring wheat (Triticum aestivum L.) cultivars. The IIOAB Journal. 1: 8-16.

Ahmadizadeh M. 2013. Physiological and agro-morphological response to drought stress. Middle-East J. Sci. Res. 13(8): 9981009.

Alam MP, S Kumar, N Ali, RP Manjhi, N Kumari, RK Lakra and T Izhar. 2013. Performance of wheat varieties under different sowing dates in Jharkhand. Journal of Wheat Research. 5(2): 61-64.

Alam MZ, SA Haider and NK Paul. 2007. Yield and yield components of barley (Hordeum vulgare L.) in relation to sowing times. J. Bio-Sci. 15:139-145.

Amgai RB, S Pantha, TB Chhetri and A Mudwari. 2013. Nepalese barley: Variation in agro-morphology characteristics. In: YP Giri, SP Khatiwada, BN Mahato, AK Gautam, MR Bhatta, JD Ranjit, BK Chhetri, RB Paneru and B Sapkota, (eds.), Proceedings of $28^{\text {th }}$ National Winter Crops Workshop, held on 9-10 March 2011, Lumle, Nepal.

Ariyo OJ. 1993. Genetic diversity in West African okra (Abelmoschus caillei) (A. Chev.) Stevels-Multivariate analysis of morphological and agronomic characteristics. Genet. Resour. Crop Evol. 40(1):25-32

Asseng S and AFV Herwaarden. 2003. Analysis of the benefits to wheat yield from assimilates stored prior to grain filling in a range of environments. Plant Soil. 256: 217-229.

Biswal AK and A Kohli. 2013. Cereal flag leaf adaptations for grain yield under drought: Knowledge status and gaps. Molecular Breeding. 31(4): 749-766.

Borner et al. 2002. Mapping of quantitative trait loci determining agronomic important characters in hexaploid wheat (Triticum aestivum L.)

Bothmer RV. 1992. The wild species of Hordeum: Relationship and potential use for improvement of cultivated barley. In: Barley: Genetics, Biochemistry, Molecular Biology and Biotechnology (PR Shewry, ed). CAB Intl., Oxford, pp. 3-18.

Chadran K and SM Pandya. 2000. Morphological characterization of Arachis species of section Arachis. Plant Genetic Resources Newsletter. 121: 38-41.

Chandrasekaran B, K Annadurai and E Somasundaram. 2010. A textbook of agronomy. New Age International Publishers, India, pp. 512.

Ekeberg E. 1994. Trials with different sowing dates in 1985-89. Norsk Landbruksforsking. 8(2): 155-75.

Eshghi R and E Akhundova. 2010. Genetic diversity in hulless barley based on agromorphological traits and RAPD markers and comparison with storage protein analysis. Afr. J. Agric. Res. 5(1): 97-107.

FAO. 2013. FAO Statistical Yearbook. Food and Agricultural Organizations of the United Nations, Rome, Italy.

Gupta SR, MP Upadhyay and US Sah. 2009. Agro-morphological variability study of barley (Hordeum vulgare L.) landraces in Jumla, Nepal. Nepal Agric. Res. J. 9: 1-11.

Kirby EJM, M Appleyard and G Fellowes. 1985. Variation in development of wheat and barley in response to sowing date and variety. The Journal of Agricultural Science. 104(2): 383-396.

Leonard D. 1982. Volume III of agricultural development workers training manual. Peace Corps, Information Collection and Exchange, Penn Center, South Carolina.

McGee H. 2004. On Food and Cooking: The Science and Lore of the Kitchen. Scribner, USA.

Mohammadi M. 2002. Effect of heat stress on grain yield components and identification of tolerant wheat (Triticum aestivum L.) cultivars. Seed Plant. 17: 400-411.

Mollasadeghi V, AA Imani, R Shahryari and M Khayatnezhad. 2011. Classifying bread wheat genotypes by multivariable statistical analysis to achieve high yield under after anthesis drought. Middle-East J. Sci. Res. 7(2): 217-220.

NeKSAP. 2015. Crop situation update. Ministry of Agricultural Development, Nepal.

Okosun LA, MD Magaji and AI Yakubu. 2006. Effect of sowing date and planting distance on growth and yield of two cultivars of roselle (Hisbiscus sabdariffa var. sabdariffa). J. Plant Sci. 1: 297-305.

Pathak S, C Poudyal, BR Ojha and S Marahatta. 2017. Evaluation of the effects of terminal heat stress on grain traits of barley (Hordeum vulgare L.) in Chitwan, Nepal. Int. J. Ag. Env. Res. 3(2): 2856-2869.

Photiades I and A Hadjichristodoulou. 1984. Sowing date, sowing depth, seed rate and rowing spacing of wheat and barley under dryland conditions. Field Crops Research. 9:151-162.

Rashid A, RU Khan, SK Marwat and Z Ali. 2010. Response of barley to sowing date and fertilizer application under rainfed condition. World Journal of Agricultural Sciences. 6(5):480-484.

Riley KW and KM Singh. 1989. Diversity and stability of barley in Nepal. IDRC Digital Library, Ottawa. 
SARE. 2012. Managing cover crops profitably. 3rd ed. Sustainable Agriculture Research and Education, University of Maryland, USA.

Savin R, PJ Stone, ME Nicolas and IF Wardlaw. 1997. Grain growth and malting quality of barley. 2. Effects of temperature regime before heat stress. Australian Journal of Agricultural Research. 48(5): 625-634.

Siddique MRB, A Hamid and MS Alam. 1999. Drought stress effects on photosynthetic rate and leaf gas exchange of wheat. Bot. Bull. Acad. Sin. 40:141-145.

Singh S and M Paul. 2003. Growth, yield and phenological response of wheat cultivars to delayed sowing. Ind. J. Plant Physiol. 8(3): 277-286.

Slafer GA and EM Whitechurch. 2001. Manipulating wheat development to improve adaptation. In: Application of physiology in wheat breeding (MP Reynolds, JI Ortiz-Monasterio and AMC Nab, eds). CIMMYT, Mexico, pp. 160-170.

Suleiman A, JF Nganya and A Ashraf. 2014. Effect of cultivar and sowing date on growth and yield of wheat (Triticum aestivum L.) in Khartoum, Sudan. Journal of Forest Products and Industries. 3: 198-203.

USDA. 1979. Barley: Origin, botany, culture, winter hardiness, genetics, utilization and pests. Agriculture Handbook No.338. U.S. Department of Agriculture, Washington D.C., USA.

$|1------||------| \mid$ 